\title{
Habitat profitability in pelagic environments
}

\author{
Dag L. Aksnes, Jarl Giske \\ Department of Marine Biology, University of Bergen, N-5065 Blomsterdalen, Norway
}

\begin{abstract}
Habitat profitability is analysed with a set of simple equations comprising predation risk, food availability, sex ratio, number of offspring per survivor, generation time and expected reproductive outcome. We show that organisms with fixed generation time should prefer hunger instead of increased feeding if the increase in feeding is associated with the same relative increase in predation risk. On the contrary, feeding is of higher reproductive value for organisms that may canalize increased feeding to a shortening of the generation time. These are more likely to tolerate increased predation risk associated with increased feeding possibilities. Generation times are often temperature dependent. The analysis indicates that an increase in environmental temperature may be more beneficial than the same relative decrease in predation risk. The theory is illustrated with data on the copepods Calanus finmarchicus and Paracalanus parvus.
\end{abstract}

\section{INTRODUCTION}

Vertical migration of aquatic animals may be regarded as habitat selection where the behaviour of the migrating organism is a result of an evolutionary maximization of fitness. The balance between feeding and predator avoidance is generally believed to be an important factor for the evolution of such migrations (e.g. Wright et al. 1980, Gliwicz 1986, Clark \& Levy 1988). Gilliam (1982) found that a feeding organism subject to predation maximizes its reproductive value and thereby its fitness during a nonbreeding period by selecting a habitat that minimizes the ratio between mortality rate and growth rate. Using the same idea Clark \& Levy (1988) assumed minimization of mortality over feeding rate instead of growth rate.

The reproductive value of survivors increases as generation time decreases and the number of offspring increases. For several organisms, both the generation time and the number of offspring depend on food intake. Thus, the value of food intake relative to predation risk may be different for organisms that are able to 'regulate' generation time and for those who cannot. The present paper presents some simple arguments that illustrate the importance of differentiating organisms into non-regulating and regulating with respect to generation time. The expressions for maximization of reproductive value are different for these groups, and consequently formulations predicting habitat profitability differ.
Temperature is decisive for generation time in many aquatic organisms, and permanent temperature gradients often characterize the water column. As temperature affects generation time, it also affects fitness. Thus, like feeding opportunites and predation risk, temperature should also be part of the habitat profitability predictor. We demonstrate the potential influence of temperature by combining mortality risk and environmental temperature in a common expression.

The theory is accompanied by earlier published data on the 2 marine copepods Calanus finmarchicus and Paracalanus parvus. We emphasize that the inclusion of these data serves as an illustration of our general equations rather than a test. Only future research may indicate the predictive ability of the present equations. Furthermore, our approach is kept to a simplistic level (i.e. age structure is not included) in order to increase the readability, and enable us to provide examples. We believe, however, that the main conclusions are not affected by this simplicity.

\section{MODEL}

In viable populations the reproductive outcome $\left(R_{0}\right)$, which is the product of number of offspring (b) per individual survivor and probability of survival (S) to maturity, is higher than, or equal to, a characteristic value, s:

$$
R_{\mathrm{o}}=\mathrm{bS} \geq \mathrm{s}
$$


In asexual organisms $s=1$, while in sexual organisms the exact value of $\mathrm{s}$ depends on the sex ratio. A male: female ratio of $1: 1$ gives $s=2$ while a ratio of $0.5: 1$ gives $s=1.5$. If $R_{0}<s$ the population will decrease and in the long run become extinct. $S$ is the probability of survival over the average generation time $\left(T_{\mathrm{g}}\right)$ in a specific habitat and will be defined:

$$
\mathrm{S}=\exp \left(-\mathrm{T}_{\mathrm{g}} \mathrm{M}\right)
$$

where $M=$ predation risk represented as the average instantaneous mortality rate characterizing the habitat. A combination of Eqs. (1) and (2) gives:

$$
\mathrm{MT}_{\mathrm{g}} / \ln (\mathrm{b} / \mathrm{s}) \leq 1
$$

According to this expression 4 variables may decrease probability of population extinction and increase individual fitness: decreased generation time, increased number of offspring, decreased number of males relative to females, and reduced mortality by habitat shift (or other means of predator avoidance).

\section{Organisms with variable generation time}

If generation time depends on growth rate (g) and feeding, we may define $T_{g}$ as the time necessary for reaching a weight $W_{1}$ when the initial weight is $W_{0}$ :

$$
W_{1}=W_{o} \exp \left(g T_{g}\right)
$$

or

$$
\mathrm{T}_{\mathrm{g}}==\ln \left(\mathrm{W}_{1} / \mathrm{W}_{\mathrm{o}}\right) / \mathrm{g}
$$

Thus, an increase in growth rate will reduce generation time. By the use of Eqs. (3) and (5) $\mathrm{T}_{\mathrm{g}}$ may be eliminated:

$$
M / g \leq \operatorname{In}(b / s) / n\left(W_{1} / W_{o}\right)
$$

If we assume that growth rate is proportional to feeding rate (f) so that $\mathrm{g}=\mathrm{kf}$, where $\mathrm{k}$ is the conversion efficiency, we obtain:

$$
\mathrm{M} / \mathrm{f} \leq \mathrm{k} \ln (\mathrm{b} / \mathrm{s}) / \ln \left(\mathrm{W}_{1} / \mathrm{W}_{0}\right)
$$

This indicates how large the ratio between mortality risk and feeding can be in order to achieve $R_{o}=s$. If the ratio $M / f$ becomes less than the right hand side of Eq. (7), the reproductive output, and thereby fitness, will increase accordingly. As given by Gilliam (1982) and Clark \& Levy (1988), a minimization of the ratio between mortality and feeding (or growth) is therefore a reasonable adaptation for populations which are able to adjust their generation time by increased feeding. It should be noted, however, that Eq. (7) does not include constraints for the feeding level (see Clark \& Levy 1988). Too low feeding may cause death and a minimum threshold value for feeding should be assumed. Nor should infinitely high feeding levels be allowed, and a maximum threshold according to handling time constraints and the functional response should be included. Our feeding parameter, f, reflects feeding rates that are within these thresholds.

\section{Variable generation time and temperature}

In several copepods, generation time is heavily influenced by water temperature. The function $\mathrm{T}_{\mathrm{g}}=$ $\mathrm{a}(\mathrm{T}+\alpha)^{-\mathrm{b}}$ describes generation time $\left(\mathrm{T}_{\mathrm{g}}\right)$ as a function of temperature ( $\mathrm{T}$ ) adequately (McLaren 1978). McLaren found that $b$ was close to 2 and $\alpha$ was correlated with the mean environmental temperature to which the animals were subjected. By inserting this temperature dependency for generation time into Eq. (3) we obtain:

$$
M / a(T+\alpha)^{2} \leq \ln (b / s)
$$

Thus, as temperature is part of a squared expression, an increase in temperature is more beneficial than the same relative decrease in mortality risk. Thus, at least for some copepods, optimal habitat choice should be more influenced by a relative change in temperature than an equal relative change in predation risk. The sharp vertical temperature gradients often found in aquatic environments may therefore strongly affect vertical distributions of the zooplankton.

\section{Organisms with fixed generation time}

The success of several boreal fishes as well as plankton depends on match between generation time and a seasonal event. Enhanced growth transformed into a shorter generation time does therefore not necessarily imply a benefit as given by Eqs. (6) and (7). An organism that lives for $1 \mathrm{yr}$, and breeds according to an annual seasonal incident (as the spring bloom), may not regulate its generation time successfully at all. A fish, however, that lives for several years may be able to reduce its generation time at a yearly scale and Eq. (7) may be valid at that time scale. In the following, however, it is assumed that it is impossible to increase the viable reproductive outcome by reducing generation time. In this case increased feeding and growth may be allocated into increased number of offspring per survivor (for example increased egg production). Thus, regarding $T_{g}$ as a constant, Eq. (3) may be restated:

$$
M / \ln (b / s) \leq T_{g}{ }^{-1}
$$

Again, if the left and right sides are equal, $R_{o}=s_{1}$ which is just enough to sustain the long-term population size. A minimization of the left hand side will increase the reproductive outcome and thereby fitness. 
According to the logarithmic relationship, a 10 -fold increase in number of offspring per survivor reduces the left side by a factor of only 2.3, while a 10-fold decrease in mortality risk leads to a 10 -fold decrease. The question is now. How is the number of offspring per survivor related to surplus food intake? Several studies on marine copepods, but also on other organisms, have revealed that adult body size increases with increased feeding during the juvenile period (e.g. Klein Breteler \& Gonzales 1982 and references therein). Furthermore, it seems reasonable to assume that fecundity depends on adult body size. Such a relationship is common in fishes, and a correlation between egg production and female size has also been found for some copepods (Checkley 1980b, Uye 1981, 1982) although other observations (Durbin et al. 1983, Smith \& Lane 1985) do not support such a relationship. For adult females, however, several studies have revealed a saturation curve for egg production versus adult food intake (Nassogne 1970, Harris 1977, Checkley 1980a, Durbin et al. 1983, Kiørboe et al. 1985, Smith \& Lane 1985). In Paracalanus parvus and Acartia tonsa, this saturation curve corresponds to the functional response, and there is a highly linear relationship between egg production rate and feeding rate (Checkley 1980a, Kiorboe et al. 1985). The conversion efficiencies (expressed in terms of biomass) between feeding and egg production were calculated as 37 and $36 \%$ for the 2 species. Thus, it seems reasonable to assume a linear relationship between egg production and feeding during the time spent as adult. The question is whether and how surplus feeding during the juvenile period (through its influence on body size) is of value for the fecundity. We assume that increased juvenile feeding increases adult body size and fecundity lineary. Specifically, we assume that fecundity is linearly dependent on the average feeding rate during the lifetime, i.e. $b=e f T_{g}$, where $e$ is the efficiency of converting food into eggs. By substitution Eq. (9) becomes:

$$
M / \ln \left(e \mathrm{~T}_{\mathrm{g}} / \mathrm{s}\right) \leq \mathrm{T}_{\mathrm{g}}{ }^{-1}
$$

Alternatively, the feeding of juveniles and adults may be treated separately and be given different influences on fecundity. We have chosen the aggregated formulation as it is unclear how the value of juvenile and adult surplus feeding should differ. A separation into juvenile and adult feeding, however, will not seriously alter the conclusions below.

Eq. (10) (fixed generation time) deviates from Eq. (7) (variable generation time) in that the value of increased feeding, which is now logarithmic in form, is considerably reduced compared to the value of reduced mortality risk. Thus, organisms depending on a match between generation time and seasonal events (or other important forcing) gain more from a decrease in mortality risk than from the same relative increase in feeding rate.

A central assumption to the above result is that surplus feeding during $T_{g}$ is allocated into tissue that does not increase future feeding rate. If the organism is able to allocate food into tissue that increases the feeding capability, and then as adult convert it into gonad tissue, feeding will be of a higher value than indicated by Eq. (10). Such conversion is therefore of adaptive value. Body-size limitations, however, restrict the potential of this adaptation, and it is very unlikely that the number of offspring can be exponentially related to the feeding rate during $\mathrm{T}_{\mathrm{g}}$.

\section{DISCUSSION}

The present simplistic model gives the following main predictions. An organism able to transform increased feeding into shorter generation time (timemanipulator) may increase its expected reproductive outcome by increased feeding more than an organism with fixed generation time (clutch-manipulator). A clutch-manipulator should prefer hunger (as long as it is not starving to death) instead of increased feeding, if a relative increase in feeding rate is associated with an equal relative increase in mortality risk. In aquatic environments where both predation risk and food sources are light-dependent (for example as a result of visual predators and photosyntetic activity), and therefore also depth dependent, clutch-manipulators should on the average be distributed deeper than time-manipulators. If potential feeding rate and predation risk are known as a function of depth (as in the model of Clark \& Levy 1988), the optimal depth is the depth that minimizes the left side of Eq. (7) (variable generation time) or Eq. (10) (fixed generation time). Furthermore, if temperature affects generation time, temperature is of paramount significance for habitat profitability as seen in Eq. (8).

We choose the herbivorous copepod Calanus finmarchicus to represent the group with fixed generation time, and Paracalanus parvus to represent animals with variable generation time. In Lindåspollene, an enclosed fjord system of Western Norway, generation time of $P$. parvus in summer has been estimated to be a few weeks (Aksnes \& Magnesen 1988). The reproduction of $C$. finmarchicus is associated with the spring diatom bloom, and generation time is 1 yr (Aksnes \& Magnesen 1983). Other C. finmarchicus populations (at least some individuals) have been reported to have several generations in the course of a year (Wiborg 1954, Ostvedt 1955, Lie 1965, Mathews et al. 1978), but a yearly generation seems to be the main pattern in 
northern areas (Lie 1965). C. finmarchicus migrates both ontogenetically and diurnally (especially the later copepodid stages). Hence, it spends a long time in deep water and both mortality risk and food intake is probably reduced. In Lindåspollene, $P$. parvus stays close to the surface, without performing diel vertical migrations (Magnesen et al. 1989). Accordingly, P. parvus is certainly subjected to increased predation risk as mortality rate for copepods is estimated to be highest in the uppermost part of the water column (Aksnes \& Magnesen 1988). However, the surface distribution certainly also increases food intake as $75 \%$ of primary production is generally located above $5 \mathrm{~m}$ depth during summer (Skjoldal et al. 1983, Aksnes et al. 1985). Furthermore, the water masses in Lindaspollene are strongly stratified, and the temperature of the surface layer during summer may approach $20^{\circ} \mathrm{C}$ which is about $10^{\circ} \mathrm{C}$ higher than at $10 \mathrm{~m}$.

\section{Fixed generation time - Calanus finmarchicus}

Let us assume that Calanus finmarchicus has a yearly generation time $\left(\mathrm{T}_{\mathrm{g}}=365 \mathrm{~d}\right)$ as observed in Lindåspollene (Aksnes \& Magnesen 1983), and an egg number in the range 300 to 3000 . If the mortality risk for the water column is known, $\mathrm{R}_{\mathrm{o}}$-values may now be calculated. In Lindåspollene, mortality risk was calculated from 10 estimates of mortality obtained for Paracalanus parvus, Pseudocalanus elongatus, Temora longicornis, Centropages hamatus and the copepodid stages of $C$. finmarchicus (Aksnes \& Magnesen 1983, 1988). These populations inhabited different parts of the water column and a depth-dependent mortality function was fitted to these estimates (Table 1, Fig. 1). An exponential relationship was used, as the light level probably influences the predation risk. Under these assumptions $R_{o}$ is extremely low in the surface layer (Table 1), and location below $70 \mathrm{~m}$ is necessary to ensure sufficient survival. C. finmarchicus, however, is a herbivore and has to face the mortality risk in the surface layer if growth (i.e. $b=300$ to 3000 and $T_{g}=365$ ) is to be realized.

There are at least 2 ways to solve this conflict. First, the copepods may allocate a relatively short time $(\mathrm{com}$ pared to the generation time) in the surface layer, but during this time growth must be sufficient to provide them with enough tissue for the rest of life. Second, they may undertake upward migrations at night so that the risk of being eaten by visual predators is reduced. Calanus finmarchicus seems to have evolved both adaptations. The nauplii and copepodids spend much of their time in the upper productive water. Furthermore, during this period growth is close to exponential (McLaren 1986) and most of the structural growth is
Table 1. Calanus finmarchicus. Reproductive output, $R_{0}$. Generation time $\left(\mathrm{T}_{\mathrm{g}}\right)$ is assumed to be $365 \mathrm{~d}$ and egg number $(\mathrm{b})$ in the range 300 to 3000 eggs female ${ }^{-1}$ The depth-dependent mortality risk is identical to that of Fig. 1

\begin{tabular}{|c|c|c|c|}
\hline \multirow{2}{*}{$\begin{array}{c}\text { Depth } \\
\text { (D) } \\
\text { (m) }\end{array}$} & \multirow{2}{*}{$\begin{array}{c}\text { Mortality } \\
\text { risk }(\mathrm{M}) \\
\left(\mathrm{d}^{-1}\right)\end{array}$} & \multicolumn{2}{|c|}{$\begin{array}{l}R_{o} \\
\text { (ind.) }\end{array}$} \\
\hline & & $b=300$ & $b=3000$ \\
\hline 1 & 0.22 & $4.0 \times 10^{-33}$ & $4.0 \times 10^{-32}$ \\
\hline 5 & 0.19 & $2.3 \times 10^{-28}$ & $2.3 \times 10^{-27}$ \\
\hline 10 & 0.15 & $5.0 \times 10^{-22}$ & $5.0 \times 10^{-21}$ \\
\hline 20 & 0.10 & $4.2 \times 10^{-14}$ & $4.2 \times 10^{-13}$ \\
\hline 50 & 0.03 & $5.3 \times 10^{-3}$ & $5.3 \times 10^{-2}$ \\
\hline 70 & 0.01 & 7.8 & 78.0 \\
\hline 90 & 0.006 & 33.6 & 335.7 \\
\hline
\end{tabular}

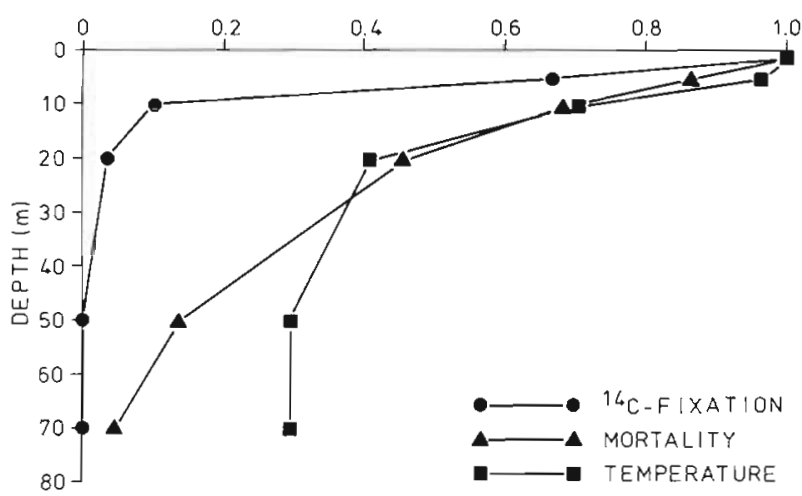

Fig. 1. Vertical distribution of temperature, carbon-fixation and zooplankton mortality in Lindåspollene. Values are scaled against the surface maxima: temperature $\left(13.5^{\circ} \mathrm{C}\right),{ }^{14} \mathrm{C}$-fixation $\left(3 \mathrm{mg} \mathrm{C} \mathrm{m}^{-3} \mathrm{~h}^{-1}\right)$ and mortality $\left(0.22 \mathrm{~d}^{-1}\right)$. Data for temperature and carbon-fixation based on Magnesen et al (1989). Mortality (M) vs depth (D) was obtained from the equation: $\log M=-0.017 \mathrm{D}-0.64\left(\mathrm{n}=10, \mathrm{r}^{2}=0.89\right)$ which was fitted to mortality estimates given by Aksnes \& Magnesen $(1983,1988)$

achieved during this period. Mortality during the intensive growth period may be as high as $0.2 \mathrm{~d}^{-1}$ and the growth rate corresponds to that of the much smaller $P$. parvus (Aksnes \& Magnesen 1988). A minor modification of Eq. (9) makes it possible to estimate time allocation between the upper water masses and the deep habitat, and the following inequality should be satisfied in order to avoid extinction:

$$
\begin{gathered}
\left(M_{1} T_{1}+M_{2} T_{2}\right) / \ln (\mathrm{b} / \mathrm{s}) \leq 1 \\
\mathrm{~T}_{1}+\mathrm{T}_{2}=\mathrm{T}_{\mathrm{g}}
\end{gathered}
$$

where $\mathrm{T}_{1}=$ time that may be spent in the surface layer with a mortality risk of $\mathrm{M}_{1} ; \mathrm{T}_{2}$ and $\mathrm{M}_{2}=$ corresponding parameters for the deep habitat. The male: female ratio for $C$. finmarchicus was found to be $0.33(s=1.33)$ in Lindaspollene (Aksnes 1981), and this means that $R_{0}$ $\geq 1.33$ in order to avoid population decrease. By inser. tion of $s=1.33, b=300, M_{1}=0.15$ (representing the upper $20 \mathrm{~m})$ and $M_{2}=0.006(90 \mathrm{~m})$ we see that $C$. 
Table 2. Paracalanus parvus. Reproductive output $\mathrm{R}_{0}$. Potential feeding was calculated from ${ }^{14} \mathrm{C}$-fixation given in Fig. 1 (see text). Fig. 1 also shows the temperature and mortality risk function used for the calculations. Generation time depends on temperature (see text), and number of eggs depend on mortality rate and potential feeding $\left(b=b_{d} f / M f_{m a x}\right)$

\begin{tabular}{|c|c|c|c|c|c|}
\hline $\begin{array}{l}\text { Depth } \\
(\mathrm{m})\end{array}$ & $\begin{array}{l}\text { Potential } \\
\text { feeding (f) } \\
\qquad\left(d^{-1}\right)\end{array}$ & $\begin{array}{c}\text { Mortality } \\
\text { risk (M) } \\
\left(d^{-1}\right)\end{array}$ & $\begin{array}{c}\text { Generation } \\
\text { time }\left(T_{g}\right) \\
\text { (d) }\end{array}$ & $\begin{array}{l}\text { No. of } \\
\text { eggs (b) } \\
\text { (ind.) }\end{array}$ & $\begin{array}{c}\mathrm{R}_{0} \\
\text { (ind.) }\end{array}$ \\
\hline 1 & 0.6 & 0.22 & 11 & 91 & 8.1 \\
\hline 5 & 0.4 & 0.19 & 12 & 70 & 7.2 \\
\hline 10 & 0.06 & 0.15 & 17 & 13 & 1.0 \\
\hline 20 & 0.02 & 0.10 & 26 & 7 & 0.5 \\
\hline 50 & 0 & 0.03 & 32 & 0 & 0 \\
\hline
\end{tabular}

finmarchicus may spend $22 \mathrm{~d}$ in the surface layer and $343 \mathrm{~d}$ in the deep habitat in order to keep constant population size. A 10 -fold doubling of egg number $(\mathrm{b}=$ 3000 ) allows for a surface exposure of $38 \mathrm{~d}$. As stated earlier $C$. finmarchicus has also evolved the other adaptation as it migrates on the diel scale. Depending on the actual reduction in mortality risk at night compared to daytime, such reduction will allow for an increased total residence time in the surface layer. This may be investigated by including daytime and nighttime mortalities and the corresponding residence times in Eq. (11). Furthermore, the number of eggs per survivor (b) may be made dependent on the residence time in the upper habitat in order to achieve more realism.

\section{Variable generation time - Paracalanus parvus}

Generation time of Paracalanus parvus is assumed to be related to temperature by the function $\mathrm{T}_{\mathrm{g}}=$ $\mathrm{a}(\mathrm{T}+\alpha)^{-2}$ (McLaren 1978). We choose the $\alpha$ given for Pseudocalanus minutus by McLaren (1978) and the parameter a to give a generation time of $12 \mathrm{~d}$ at $13^{\circ} \mathrm{C}$ (Sonntag \& Parslow 1981, Aksnes \& Magnesen 1988). Potential feeding was assumed to be proportional to ${ }^{14} \mathrm{C}$-fixation rate (Fig. 1) found during a $3 \mathrm{wk}$ summer period in Lindasspollene (Magnesen et al. 1989), and the uppermost meter of the water column was assumed to give a realized feeding rate of $0.6 \mathrm{~d}^{-1}$ (denoted $\mathrm{f}_{\max }$ below). This is in accordance with the experimental studies of Paffenhöfer (1984) giving a daily feeding rate of 48 to $82 \%$ of body weight, and the field study of Aksnes \& Magnesen (1988) giving a growth rate of about $0.3 d^{-1}$. As suggested by several experimental studies on copepods, it is assumed that the egg-laying rate is proportional to food availability: Checkley (1980b) reports on average in situ estimated rate of 18 eggs $\mathrm{d}^{-1}$ with an average chlorophyll a concentration of $1.53 \mathrm{mg} \mathrm{m}^{-3}$, while Kiørboe et al. (1988) found a rate of about 10 eggs $d^{-1}$ female $^{-1}$. The experimental work of Checkley (1980a) indicates an average maximum production of 53 eggs $\mathrm{d}^{-1}$ female $^{-1}$ at high food densities. In the present calculations we assume a maximum value of 20 eggs $d^{-1}\left(b_{d}\right)$ in the uppermost meter as the food densities are generally lower than in our situation. The realized number of offspring (b), however, depends on the survival of the females. An instantaneous mortality rate of $0.22 \mathrm{~d}^{-1}$ gives a total maximum egg production of $\mathrm{b}_{\max }=\mathrm{b}_{\mathrm{d}} \int \exp (-\mathrm{Mt}) \mathrm{dt}=\mathrm{b}_{\mathrm{d}} / \mathrm{M}$

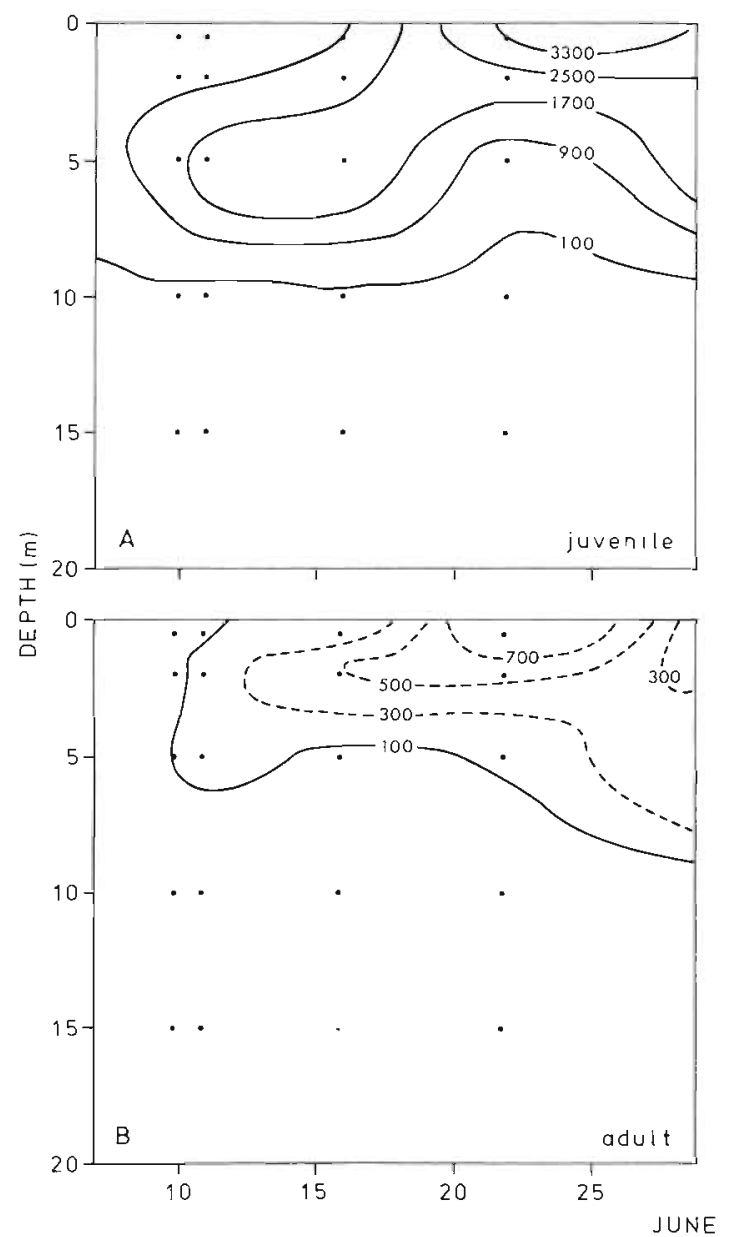

Fig. 2. Paracalanus parvus. Vertical distribution (ind. $\mathrm{m}^{-3}$ ) in Lindåspollene during June, 1981 (from Aksnes \& Magnesen 1988) 
$=20 / 0.22=91$ eggs female ${ }^{-1}$. Thus, in our calculations in Table 2, number of offspring at a particular depth (b) is assumed to depend on both food availability and predation risk through the relationship $b=b_{d} f /\left(\mathrm{Mf}_{\max }\right)$. On the basis of the environmental forcing given in Fig. 1, we calculated habitat profitability for $P$. parvus (Table 2). Here, we see that the habitat above $5 \mathrm{~m}$ is the best. This is in accordance with the observed distribution of $P$. parvus in Lindåspollene (Fig. 2). Furthermore, $P$. parvus exhibited no diel vertical migration (Magnesen et al. 1989), which is in accordance with the $R_{0}$ values in Table 2 indicating no adaptional value of migration into deeper water.

\section{CONCLUSION}

The present theory and examples indicate how widely the habitat profitability may differ for organisms with fixed versus variable generation time. Accordingly, realistic expressions predicting the habitat profitability should take into account both the quantity of feeding and the reproductive value of feeding as this differs depending on how the energy is allocated: to a shortening of the generation time (Eq. 7) or to an increased number of offspring (Eq. 10) or both. Organisms with the first adaptation may be termed timemanipulators, while clutch-manipulators is a more appropriate term for the other adaptation. Clark \& Levy (1988) arrived at an descriptor where the optimum habitat is given by a minimization of mortality over feeding rate $(\mathrm{M} / \mathrm{f})$. We obtain the same result for the time manipulators. If generation time is controlled by temperature, however, the environmental temperature is part of optimum habitat descriptors and temperature changes may be more important than corresponding changes in predation risk. Additionally, for clutchmanipulators the significance of feeding is depressed by the ln-operator as given by Eq. (10).

Acknowledgements. This work was supported by the Norwegian Research Council for Science and the Humanities (NAVF). We thank Ulf Lie, Ulf Bamstedt and 2 anonymous referees for valuable comments and criticism

\section{LITERATURE CITED}

Aksnes, D. L. (1981). Undersokelse av zooplankton populasjonsdynamikk i Lindåspollene, 1979. Cand. real. thesis, Univ. of Bergen, Norway

Aksnes, D. L., Macrnesen, T (1983). Distribution, development, and production of Calanus finmarchicus (Gunnerus) in Lindåspollene, western Norway, 1979. Sarsia 68: $195-208$

Aksnes, D. L., Magnesen. T (1988). A population dynamics approach to the estimation of four calanoid copepods in
Lindåspollene, western Norway. Mar. Ecol. Prog. Ser. 45: $57-68$

Aksnes, D. L., Magnesen, T., Lie, U. (1985). Nutrient enrichment experiments in plastic cylinders and the implications of enhanced primary production in Lindåspollene, western Norway. Sarsia 70: 45-58

Checkley, D. M. (1980a). The egg production of a marine planktonic copepod in relation to its food supply: laboratory studies. Limnol. Oceanogr 25: 430-446

Checkley, D. M. (1980b). Food limitation of egg production by a marine, planktonic copepod in the sea off southern California. Limnol. Oceanogr. 25: 991-998

Clark, C. W., Levy, D. A (1988). Diel vertical migrations by juvenile sockeye salmon and the antipredation window. Am. Nat. 131: 271-290

Durbin, E. G., Durbin, A. G., Smayda, T J., Verity, P. G. (1983). Food limitation of production by adult Acartia tonsa in Narraganset Bay, Rhode Island. Limnol. Oceanogr 28: $1199-1213$

Gilliam, J. F. (1982). Habitat use and competitive bottlenecks in size-structured fish populations. Ph. D. diss., Michigan State University, East Lansing

Gliwicz, Z. M. (1986). Predation and evolution of vertical migration in zooplankton. Nature, Lond. 320: 746-748

Harris, R. P. (1977). Some aspects of the biology of the harpacticoid copepod, Scottolana canadensis (Willey), maintained in laboratory culture. Chesapeake Sci. 18: 245-252

Kiørboe, T., Møhlenberg, F., Hamburger, K. (1985). Bioenergetics of the planktonic copepod Acartia tonsa: relation between feeding, egg production and respiration, and composition of specific dynamic action. Mar Ecol. Prog. Ser. 26: 85-97

Kiørboe, T., Møhlenberg. F., Tiselius, P. (1988). Propagation of planktonic copepods: production and mortality of eggs. In: Boxshall, G. A., Schminke, H. K. (eds.) Biology of copepods. Kluwer Academic Publishers, Dordrecht, p. 219-225

Klein Breteler, W C. M., Gonzales, S. R. (1982). Influence of cultivation and food concentrations on body length of calanoid copepods. Mar. Biol. 71: 157-161

Lie, U. (1965). Quantities of zooplankton and propagation of Calanus finmarchicus at permanent stations at Spitsbergen, 1959-1962. Fisk Dir. Skr. (Ser Havunders.) 13: $5-19$

Magnesen, T., Aksnes, D. L., Skjoldal, H. R. (1989). Fine-scale vertical structure of a summer zooplankton community in Lindåspollene, western Norway. Sarsia 74: 115-126

Matthews, J. B. L., Hestad, L., Bakke, J. L. W. (1978). Ecological studies in Korsfjorden, western Norway. The generations and stocks of Calanus hyperboreus and C. finmarchicus in 1971-1974. Oceanologica Acta 1. 274-284

McLaren, I. A. (1978). Generation lengths of some temperate copepods: Estimation, prediction, and implications. J. Fish. Res. Bd Can. 35: 1330-1342

McLaren, I. A. (1986). Is 'structural' growth of Calanus potentially exponential? Limnol. Oceanogr. 31: 1.342-1346

Nassogne, A. (1970). Influence of food organisms on the development and culture of pelagic copepods. Helgoländer Wiss. Meeresunters. 20: 333-345

Østvedt, O. J. (1955). Zooplankton investigations from weather ship $M$ in the Norwegian Sea, 1948-1949. Hvalrầd. Skr. 40: 1-93

Paffenhofer, G.-A. (1984). Food ingestion by the marme planktonic copepod Paracalanus in relation to abundance and size distribution of food. Mar. Biol. 80: 323-333

Skjoldal, H. R., Johannesen, P., Klinken, J., Haldorsen, H. (1983). Controlled ecosystem experiment in Lindåspollene, 
western Norway, June 1979: comparison between the natural and two enclosed water columns. Sarsia 68: 47-64

Smith, S. L., Lane, P. V Z. (1985). Laboratory studies of the marine copepod Centropages typicus: egg production and development rates. Mar. Biol. 85: 153-162

Sonntag, C. S., Parslow, J. (1981). Technique of systems identification applied to estimating copepod production. J. Plankton Res. 3: 461-473

Uye, S. (1981). Fecundity studies of neritic calanoid copepods Acartia clausi Giesbrecht and A. steuri Smirnov: a simple empirical model of daily egg production. J. exp. mar. Biol. Ecol. 50: 255-271

This article was submitted to the editor
Uye, S. (1982). Population dynamics and production of Acartia tonsa Giesbrecht (Copepoda: calanoida) in inlet waters. J. exp. mar. Biol. Ecol. 57: 55-83

Wiborg, K. F. (1954). Investigations of zooplankton in coastal and offshore waters of western and northwestern Norway. Fisk Dir Skr (Ser. Havunders.) 11 1-246

Wright, D., O'Brien, W J., Vinyard, G. L. (1980). Adaptive value of vertical migration: a simulation model argument for the predation hypothesis. In: Kerfoot, W. C. (ed.) Evolution and ecology of zooplankton communities, University Press of New England. Hanover, $\mathrm{NH}$, p. $138-147$

Manuscript first received: November 14, 1989

Revised version accepted: April 11, 1990 